\title{
A STUDY TO CORRELATE LOW SERUM IRON LEVELS WITH GALLSTONES
}

\author{
${ }^{1}$ Professor, Department of Surgery, Krishna Institute of Medical Sciences, Karad. \\ ${ }^{2}$ Resident, Department of Surgery, Krishna Institute of Medical Sciences, Karad. \\ ${ }^{3}$ Resident, Department of Surgery, Krishna Institute of Medical Sciences, Karad. \\ ${ }^{4}$ Resident, Department of Surgery, Krishna Institute of Medical Sciences, Karad. \\ ${ }^{5}$ Resident, Department of Surgery, Krishna Institute of Medical Sciences, Karad. \\ ${ }^{6}$ Resident, Department of Surgery, Krishna Institute of Medical Sciences, Karad.
}

Ashok Y. Kshirsagar¹, Madhavendra Varadraj Kabra², Mahesh Reddy³, Shruti Panicker, Ujwal kumar 5 , Aditya Phadke 6

\section{ABSTRACT}

Gallstone disease is a common ailment encountered in day-to-day practice affecting the adult population of both sexes. The common belief that a typical gallstone disease affects a fat, fertile, female of fifty, is only partially true, as the disease is found in both the sexes of varying age groups and also in underweight and thin people. Recent studies have demonstrated the role of iron deficiency and defective $\mathrm{pH}$ in the formation of gallstones.

\section{AIMS}

To establish the role of iron deficiency in the formation of gallstones.

\section{MATERIALS AND METHODS}

One hundred and twenty patients were studied prospectively over a period of two years in Department of General Surgery at Krishna Institute of Medical Sciences, Karad. Serum iron and serum cholesterol levels of patients suffering from cholelithiasis were compared with healthy individuals. Data amongst the two groups were subjected to statistical analysis was using students $t$-test. The P-value $<0.05$ was considered significant.

\section{OBSERVATIONS AND RESULTS}

Most of the patients with gallstones had low serum iron levels. Serum cholesterol levels of patients suffering from cholelithiasis were not significantly different from that of normal healthy individuals.

\section{CONCLUSION}

Low serum iron levels lead to bile super-saturation with respect to cholesterol, which leads to gallstone formation.

\section{KEYWORDS}

Gallstones, Serum Iron, Serum Cholesterol.

HOW TO CITE THIS ARTICLE: Kshirsagar AY, Kabra MV, Reddy M, et al. "A study to correlate low serum iron levels with gallstones”. Journal of Evolution of Medical and Dental Sciences 2015; Vol. 4, Issue 104, December 28; Page: 16912-16914,

DOI: $10.14260 /$ jemds/2015/2546

\section{INTRODUCTION}

As per the popular belief that a typical gallstone sufferer is a fat, fertile, female of forty, is only partially true, as the disease has been found in women soon after their first delivery and also in underweight and thin people. So while searching the literature for different factors, iron deficiency was found to be new and interesting etiological factor in the formation of gallstones.[1,2]

Gallstones may produce several symptoms or may remain asymptomatic. Over half the cases are asymptomatic, usually detected by abdominal ultrasound. Today, the incidence of gallstone disease has increased considerably with the invention of ultrasonography.

\section{Three conditions must be met to permit the formation of cholesterol gallstones \\ 1. Bile must be supersaturated with cholesterol. \\ 2. Nucleation must be kinetically favorable. \\ 3. Cholesterol crystals must remain in the gallbladder long enough to agglomerate into stones.}

Financial or Other, Competing Interest: None.

Submission 07-12-2015, Peer Review 08-12-2015,

Acceptance 23-12-2015, Published 24-12-2015.

Corresponding Author:

Dr. Madhavendra Varadraj Kabra,

Room No. 13,

IHR Hostel, KIMS,

Karad.

E-mail:drmaddy7888@gmail.com

DOI:10.14260/jemds/2015/2546
Iron deficiency has been shown to alter the activity of several hepatic enzymes, leading to increased gallbladder bile cholesterol saturation and promotion of cholesterol crystal formation.

Iron acts as a coenzyme for Nitric Oxide Synthetase (NOS), which synthesize Nitric Oxide (NO) and that is important for maintenance of basal gallbladder tone and normal relaxation. It was found that iron deficiency resulted in altered motility of gallbladder and sphincter of Oddi leading to biliary stasis and thus increased cholesterol crystal formation in the gallbladder bile.

\section{AIM AND OBJECTIVE}

To establish the role of iron deficiency in the formation of gallstones.

\section{MATERIAL AND METHODS}

One hundred and twenty patients were studied prospectively over a period of two years in Department of General Surgery at Krishna Institute of Medical Sciences, Karad. Serum iron and serum cholesterol levels of patients suffering from cholelithiasis were compared with healthy individuals. Research committee of the institute approved the protocol. Study group included 60 pts. suffering from cholelithiasis admitted in Krishna Hospital, Karad, confirmed by USG. Control group consisted of 60 healthy individuals.

In the control group individuals with liver cirrhosis, hematological disorders, cystic fibrosis, pyruvate kinase deficiency and pts. on long term hepato-toxic drugs and other drugs causing gallstones and pregnant females were excluded. 
Serum iron was estimated by Ferrozine kit method.[3] The normal reference values were supplied with the kit, for males (60-160ug/dl) and for females (35-145ug/dl). Serum cholesterol was estimated by CHOD-PAP kit based on cholesterol oxidase/peroxidase method as devised by Allainet al.[4]

\section{RESULTS}

\begin{tabular}{|c|c|c|c|c|c|}
\hline Sl & \multirow{2}{*}{$\begin{array}{c}\text { Norum } \\
\text { Iron }\end{array}$} & \multicolumn{2}{|c|}{ Cases } & \multicolumn{2}{c|}{ Control } \\
\cline { 3 - 6 } & & $\begin{array}{c}\text { Anaemic } \\
\text { No. (\%) }\end{array}$ & $\begin{array}{c}\text { Non-Anaemic } \\
\text { No. (\%) }\end{array}$ & $\begin{array}{c}\text { Anaemic } \\
\text { No. (\%) }\end{array}$ & $\begin{array}{c}\text { Non-Anaemic } \\
\text { No. (\%) }\end{array}$ \\
\hline 1 & $<$ Normal & $32(53.3 \%)$ & $13(21.7 \%)$ & $4(6.6 \%)$ & $25(41.7 \%)$ \\
\hline 2 & Normal & $6(10 \%)$ & $9(15 \%)$ & 0 & $31(51.7 \%)$ \\
\hline 3 & $>$ Normal & 0 & 0 & 0 & 0 \\
\hline 4 & Total & 38 & 22 & 4 & 56 \\
\hline \multicolumn{7}{|c|}{ Table 1 } \\
\hline
\end{tabular}

\section{Table No. 1: Shows the following:}

1. $75 \%$ of the pts. with gallstones have values of serum iron less than normal.

2. $53.3 \%$ of the pts. in case group with low serum iron are anemic.

3. $48.3 \%$ of healthy individuals have low serum iron.

4. $6.6 \%$ of control group who have low serum iron are anemic.

5. Most of the pts. with gallstones have serum iron levels less than normal and they are anemic.

\begin{tabular}{|c|c|c|c|c|c|}
\hline \multirow[b]{2}{*}{$\begin{array}{l}\text { Sl } \\
\text { No. }\end{array}$} & \multirow[b]{2}{*}{$\begin{array}{c}\text { Serum } \\
\text { Cholestrol }\end{array}$} & \multicolumn{2}{|c|}{ Cases } & \multicolumn{2}{|c|}{ Control } \\
\hline & & $\begin{array}{c}\text { Anaemic } \\
\text { No. (\%) }\end{array}$ & $\begin{array}{c}\text { Non-Anaemic } \\
\text { No. (\%) }\end{array}$ & $\begin{array}{c}\text { Anaemic } \\
\text { No. (\%) }\end{array}$ & $\begin{array}{c}\text { Non- } \\
\text { Anaemic } \\
\text { No. (\%) }\end{array}$ \\
\hline 1 & $<$ Normal & $14(23.3 \%)$ & $7(11.7 \%)$ & $1(1.7 \%)$ & $18(30 \%)$ \\
\hline 2 & Normal & $19(31.7 \%)$ & $17(28.3 \%)$ & $2(3.3 \%)$ & $38(63.3 \%)$ \\
\hline 3 & $>$ Normal & $3(5 \%)$ & 0 & 0 & $1(1.7 \%)$ \\
\hline 4 & Total & 36 & 24 & 3 & 57 \\
\hline
\end{tabular}

Table No. 2: Shows the following:

1. $23.3 \%$ of anemic and $11.7 \%$ of non-anemic patients with gallstones have less than normal serum cholesterol levels, which is $1.7 \%$ and $30 \%$ in normal healthy individuals respectively.

2. $31.7 \%$ of anemic and $28.3 \%$ of non-anemic pts. with gallstones have normal serum cholesterol levels, which is $3.3 \%$ and $63.3 \%$ in normal healthy individuals respectively.

3. There is no effect of anemia on serum cholesterol.

\section{DISCUSSION}

Iron deficiency has been shown to alter the activity of several hepatic enzymes leading to increased gallbladder cholesterol saturation and promotion of cholesterol crystal formation. $[5,6]$ Iron acts as a coenzyme for Nitric Oxide Synthetase (NOS), which synthesizes Nitric Oxide (NO) important for the maintenance of gallbladder tone and normal relaxation. ${ }^{7,8]}$ Alteration of motility of the gallbladder and sphincter of Oddi leading to biliary stasis resulting in cholesterol crystal formation has been reported with iron deficiency.[9]

The present study shows that the gallbladder bile cholesterol level was significantly higher in the anemic individuals, as compared to that of the non-anemic patients. Further, no significant variation in the serum cholesterol values was detected between the anemic group and the nonanemic group.

This study suggests that iron deficiency anemia is playing a significant role in the super-saturation of gallbladder bile with cholesterol and may act as an independent factor in formation of cholesterol gallstones. Defective hepatic cholesterol metabolism and stasis of bile because of decreased motility of the gallbladder can lead to more precipitation of cholesterol and hence formation of gallstones.[10,11]

\section{CONCLUSION}

In the present prospective study of 120 cases based on serum iron, serum cholesterol and hemoglobin, the following conclusions were drawn:

1. The low serum iron level in one or the other way was leading to bile super-saturation with respect to cholesterol which leads to gallstone formation.

2. Serum total cholesterol of pts. of cholelithiasis was not different from that of general population. There were no significant variations in the serum cholesterol contents of both the groups.

\section{REFERENCES}

1. Strasberg SM, Clavien PA, Harvey PR. Pathogenesis of cholesterol gallstones. HPB Surg 1991;3(2):79-102.

2. Verma GR, Pandey AK, Bose SM, et al. Study of serum calcium and trace elements in chronic cholelithiasis. Aust NZ J Surg 2002;72:596-9.

3. Siedel J, Wahlefeld AW, Ziegenhorn J. A new iron Ferrozine reagent without deproteinization. ClinChem 1984;30:975.

4. Allain CC, Poon LS, Chan CS, et al. Enzymatic determination of total serum cholesterol. ClinChem 1974;20(4):470-5. 
5. Roslyn JJ, Conter RL, Julian E, et al. The role of dietary iron in pigment gallstone formation. Surgery 1987;102:327-33.

6. Johnston SM, Murray KP, Martin SA, Fox-Talbot K, Lipsett $\mathrm{PA}$, Lillemoe $\mathrm{KD}$, et al. Iron deficiency enhances cholesterol gallstone formation. Surgery 1997;122:354-61.

7. Swartz-Basile DA, Goldblatt MI, Blaser C, Decker PA, Ahrendt SA, Sarna SK. Iron deficiency diminishes gallbladder neuronal nitric oxide synthase. J Surg Res 2000;90:26-31.
8. Salomons H, Keaveny AP, Henihan R, Offner G, Sengupta A, Lamorte WW, et al. Nitric oxide and gallbladder motility in prairie dogs. Am J Physiol 1997;272:G770-8.

9. Goldblatt MI, Swartz-Basile DA, Choi SH, Rafiee P, Nakeeb A, Sarna SK, et al. Iron deficiency transiently suppresses biliary neuronal nitric oxide synthase. J Surg Res 2001;98:123-8.

10. Kumar M, Goyal BB, Mahajan M, et al. Role of iron deficiency in the formation of gallstones. Indian J Surg 2006;68:80-3.

11. Prasad PC, Gupta S, Kaushik N. To study serum iron levels in patients of gallbladder stone disease and to compare with healthy individuals. Indian J Surg 2015;77:19-22. 